\title{
THINKING CATASTROPHIC THOUGHTS: A TRAUMATIZED SENSIBILITY ON A HOTTER PLANET
}

\author{
Susan Kassouf ${ }^{1}$
}

While catastrophizing has traditionally been pathologized within psychoanalytic traditions, in this paper I suggest that cataclysmic realities of climate change call upon all of us to cultivate catastrophic thinking. Our new climatic normal demands of us not only new concepts and language, but also a new sort of thinking, building on Wilfred Bion's ideas that to think is to use our mind's capacity to be in touch with internal and external realities. I suggest that sometimes people are able to learn from their experiences of trauma in ways that disrupt the culturally dominant anenvironmental orientation, that is, an orientation that brackets out the more-thanhuman environment. Instead, they develop a capacity to think catastrophically about and to be permeable to the more-than-human environment. What I call their "traumatized sensibility" can offer guidance as we come to co-exist with and respond more consciously to our hotter planet.

KEY WORDS: anenvironmental orientation; Wilfred Bion; catastrophic thinking; climate change; despair; more-than-human environment; trauma; traumatized sensibility

https://doi.org/10.1057/s11231-022-09340-3

Catastrophize: to imagine the worst possible outcome of an action or event: to think about a situation or event as being a catastrophe or having a potentially catastrophic outcome.

- Merriam Webster Dictionary

Someday, perhaps not long from now, the inhabitants of a hotter, more dangerous and biologically diminished planet than the one on which I lived may wonder what you and I were thinking, or whether we thought at all.

-William Vollmann, Carbon Ideologies

Susan Kassouf, Ph.D., Licensed Psychoanalyst and candidate, National Psychological Association for Psychoanalysis (NPAP). Co-founder, Steps on Sustainability Committee, NPAP.

Address correspondence to Susan Kassouf, Ph.D., National Psychological Association for Psychoanalysis, 40 West 13th St, New York, NY 10011, USA. Email: kassouf@bestweb.net 
The phrase "catastrophic thinking" was first articulated in 1962 (Ellis), and its meaning has not changed much since. Those who indulge are busy turning molehills into mountains, afflicted with premature, disproportionate or paranoid panic. A quick internet search finds the term, among other places, used clinically to describe symptoms (see Psychology Today online or the Psychoanalytic Electronic Publishing Archive) or colloquially to admonish and insult. In other words, should you find yourself overreacting in this manner, knock it off. And indeed, Psychology Today offers a helpful on-line posting about how to do exactly that: "5 Ways to Stop Catastrophizing" (Bonoir, 2016).

This paper is an invitation not to stop but to start catastrophizing. In terms of anthropogenic climate change, "it is worse, much worse, than you think," as David Wallace-Wells reminds us in The Uninhabitable Earth (Wallace, 2019 , p. 3). These cataclysmic realities, which include the zoonotic corona virus, call upon us to develop our capacities to think catastrophically, a call that psychoanalysis is poised to help us answer. Our new climatic normal demands of us not only new concepts and language (see, for example, Albrecht, 2020), but also a new sort of thinking, building on Wilfred Bion's ideas that to think is to use our mind's capacity to be in touch with internal and external realities (1957, p. 271).

In "The Psycho-Analytic Study of Thinking," Bion (1962) builds on Freud's (1911) "Formulations on the Two Principles of Mental Functioning," to describe his ideas about thinking as relates to frustration. Tolerance of frustration leads to its modification, that is, a thought and the development of an apparatus for thinking. Intolerance of frustration leads to the evasion of thought, often by destructive attacks. Bion, like Freud, explores frustration using the context of the mother-infant dyad and the infant's experience of breast or no-breast: "If the capacity for toleration of frustration is sufficient the 'no-breast' inside becomes a thought, and an apparatus for 'thinking' it develops" (Bion, 1962, p. 307). Although both Freud and Bion developed these psychoanalytic theories about thinking at different moments in the climatically stable 20th century, their theories share a historical indebtedness to the idea of a bourgeois, nuclear family and the primacy of the mother-infant bond.

Extending these theories beyond their historical context and focus on the mother-infant bond to the more-than-human environment may illuminate ways to engage with anthropogenic climate change. Such an extension seems in keeping with Freud's own interest in the "relation of neurotics and of mankind in general to reality" and his desire to bring "the psychological significance of the real external world into the structure of our theories" (Freud, 1911, p. 218). At present, the real external world confronts us-not with frustration or no-breast—but with a sixth extinction, a catastrophe-not 
no mother, but possibly no human species. Recall the etymology of catastrophe: "Katastrophé, a lit overturning (kata, down) hence a fig upsetting, hence a conclusion, esp. in drama, of a tragedy, hence ruin, a great misfortune" (Partridge, 1958, p. 673).

In our waning era of petromodernity, most of us are, to differing degrees, witnessing participants in an overturning of those climate systems that made earth habitable for much of life as we know it. Can we overturn our thinking in response? I suggest that developing our capacity to think catastrophic thoughts may allow us to make meaningful contact with these evolving realities, enabling us to translate thought into long overdue action and make change in the world. (Bion, 1962, p. 309; see also Freud, 1911, pp. 219 and 221).

Many analytically-minded people working in this area are leading the way in showing how psychoanalysis can aid our understanding of dynamics around, for example, denial, dissociation, and narcissism (see for example Allured, 2018; Gentile, 2020; Lifton, 2017; Orange, 2016; and Weintrobe, 2012). And many beyond psychoanalysis grappling with ecological breakdown point to a need for a new kind of thinking, such as Stacey Alaimo's consideration of "exposure" (2016), Jem Bendell's ideas of "deep adaptation" (2018) and Timothy Morton's ingenious "hyperobjects" (2013). Morton in his Dark Ecology (2016), which uses some permutation of "think" over 200 times in a book with far fewer pages, moves in a similar vein, trying to distinguish between Easy Think and Difficult Think.

I draw upon many of these ideas and others, such as Thomas Ogden's description of "transformative thinking" (Ogden, 2010, p. 320), in order to explore some of the following cultural and clinical questions. What might we learn from people who are thinking catastrophically, in other words from those who are deeply open to what is happening on our planet? Or, what might we learn from those moments when people open themselves up to it? What enables some to disrupt a still prevailing "anenvironmental" orientation, that is, an orientation that brackets out the more-than-human environment? ${ }^{2}$ How do some adopt a sensibility permeable to the morethan-human environment and our traumatizing reality?

Asking these questions invites us to revisit and re-contextualize our ideas about trauma, one of the conflicted cornerstones of psychoanalysis (Herman, 1992; Woodbury, 2019). As Zhiwa Woodbury points out in his discussion of what he calls Climate Trauma, at present "we lack the necessary psychological framework for understanding the dynamics of this [climate] crisis" (Woodbury, 2019, p. 3). My own enactments of an anenvironmental orientation during my training as well as a hesitance to think catastrophically as an analyst brought this lack home to me in the form of clinical moments I did not explore. Despite these missed opportunities, I 
have found in my own practice as well as in interactions with dedicated colleagues working in this area that some are able to learn from their usually early experiences of interpersonal trauma in ways that translate to a capacity to think catastrophically about the more-than-human environment. What I call their "traumatized sensibility" can offer guidance as we come to co-exist more consciously with evolving and dangerous external realities.

\section{CULTURAL AND CLINICAL CATASTROPHIC THINKING}

Although a controversial figure in political as well as environmental circles, former Vice President Al Gore could arguably be credited with bringing unprecedented attention to anthropogenic climate change in the 2006 documentary An Inconvenient Truth (Guggenheim, 2006). This iconic film offers a poignant, perhaps even foundational, origin story of one individual's engagement with climate change, in effect, Gore's journey toward catastrophic thinking. The documentary shows Gore directly linking his young son's involvement in a near fatal car accident with his willingness to confront the realities of climate change:

April $3^{\text {rd }}, 1989$, my son pulled loose from my hand and chased his friend across the street. He was 6 years old. The machine was breathing for him. We were possibly going to lose him. He finally took a breath. We stayed in the hospital for a month, it was almost as if you could look at that calendar [...] and everything flew off, it was trivial, insignificant [...] It just turned my whole world upside down and then shook it until everything fell out. My way of being in the world, it just changed everything for me. How should I spend my time on this earth? I really dug in, trying to learn about it, trying to learn about it much more deeply. I went to Antarctica, went to the South Pole, the North Pole, the Amazon, went to places where scientists could help me understand parts of the issue I didn't really understand in depth, the possibility of losing what was most precious to me. I gained an ability that maybe I didn't have before, but when I felt it, I felt that we could really lose it, that what we take for granted might not be here for our children [my emphasis]. (Gore, 2006, p. 16).

Gore links the etymological roots of his personal catastrophe- "it just turned my whole world upside down" — with the larger planetary catastrophe at hand. This is not the only place in which the film shows Gore speaking about the motivating interpersonal traumas behind his engagement with climate change, his translation of thought into action. He also touches on the death of his sister from smoking-related lung cancer which led to his family giving up tobacco farming as well as the trauma of narrowly losing the 2000 election to George Bush, with the help of a US Supreme Court decision. The film illuminates how these traumas or 
catastrophic overturnings of his world, personal and otherwise, give Gore the ability to think about, and act upon, larger ones.

As my own capacity to disrupt the prevailing anenvironmental orientation of clinical work grew, I found myself more able to listen analytically to and for moments when the more-than-human environment, specifically climate breakdown, appeared in sessions. A phenomenon similar to that depicted in An Inconvenient Truth emerged. Catastrophic thinking took place with those whose interpersonal trauma had not broken them but broken them open, making them aware of their own permeability in generative, livable ways. ${ }^{3}$ Using clinical vignettes, modified to protect confidentiality, I offer some examples of people who have learned from their experiences of trauma in a manner that allowed them to disrupt the still psychically and clinically dominant anenvironmental orientation and to stay open to their experience of environmental destruction. Instead of remaining in a traumatized state, they possess a traumatized sensibility, not working through or past their traumatic experiences, but with and in them.

In developing the idea of a traumatized sensibility, I do not wish to suggest that experiences of early or systemic trauma necessarily lead to awareness of ecological degradation or that this is the only path to such awareness. Fortunately, and perhaps obviously, there are many ways that people do (and do not) come to feel, think and act upon the realities of climate breakdown. My exploration of a traumatized sensibility, therefore, stems from a desire to expand our understanding of these ways rather than exclude others. My exploration, too, is likely generationally determined. The vignettes I describe took place over a four-year period between 2015 and 2019 in a pre-pandemic New York City, a time and a place in which it was still possible for too many of us to pretend climate breakdown was happening elsewhere, if it were to happen at all. Young people and babies being born today into a landscape charred by wildfires or coastlines flooded by rising seas will inhabit a world in which the on-going trauma of a sixth extinction was always already there. Climate activist Jamie Margolin, born in 2001, makes this clear when she describes the defining feature of her generation: "not really believing in the future" (Jarvis, 2020, p. 30).

Anna, a white, Jewish, middle-class woman in her 30s with whom I had worked for several years, had never mentioned climate change or environmental degradation in a session. Suddenly, after the 2018 Pittsburgh synagogue shootings which severely shook her, she explained that not a day went by when she did not think about climate change. Something about this catastrophe in Pittsburgh, which recalled the transgenerational trauma of both sets of her grandparents fleeing anti-Semitic persecution abroad, seemed to open her up and let climate change explicitly in the room. Tellingly, it took an event of powerful horror to disrupt our tacitly shared 
clinical silence about the more-than-human environment. This silence can be understood as part of the unconscious dissociative pull described by Lynne Layton, which separates individuals from their social contexts (Layton, 2006, p. 107) and, I would add, from their ecological contexts as well. We both had unconsciously internalized the anenvironmental orientation of the psychoanalytic frame and the larger culture to which it belongs. Recalling the Victorians' hesitancy to speak directly about sex, we 21 st century heirs to a petromodern legacy find ourselves hard-pressed to speak about ourselves as part of a more-than-human environment, ${ }^{4}$ now spiraling out of control.

Unlike Anna, Harold made frequent and direct mention of his concerns about the changing climate, mention that often struck me dumb in every sense of the word. Although I became a psychoanalyst in part because of an interior struggle to tolerate strong feelings around catastrophic climate change, my own otherwise comprehensive training did not offer much guidance on how to allow for an awareness of the more-than-human environment in my practice. ${ }^{5}$ While not a drive theorist, I had internalized statements such as that used by Mitchell and Greenberg in their textbook Object Relations in Psychoanalytic Theory to describe drive theory: "The unit of study of psychoanalysis is the individual, the discrete organism which can be conceptualized and studied outside of the environment into which he is born" (Mitchell \& Greenberg, 1983, p. 342). Given the enormity of my own countertransferential terror, rage and sadness, I feared I would not be able to speak to Harold's in any analytically helpful way. Unable to speak, afraid to weep, I could only listen.

And so, I listened to twenty-something Harold, a single, heterosexual, biracial artist, as he spoke about the conflict between his aspirations and his dread of what the future holds for all of us. He asked repeatedly, plaintively, what sense does it make to meet someone and raise children on a rapidly destabilizing planet? Harold had endured an extremely abusive, neglectful childhood, particularly at the hands of one of his parents. After our work together ended, I found myself returning to my notes, wondering if I might see anything different happening in sessions with someone so open to climate change and its meanings, and who brought that into our work explicitly. I was surprised to see how almost every session began with a comment on the weather, although by now I was far less surprised to see that my internalization of the anenvironmental frame had led me to miss this fact completely while working with Harold: 
It is still raining, it was an adventurous commute to get here, also with the wind being so crazy.

Biking here is a little crazy, it looks nice out, but there's a chill in the air.

I biked here, in so many layers. It has been a while since it felt safe to bike here, not so good on ice and snow.

It is really cold out, they warned me about that, I'm used to everything being within $20^{\circ}$, people said mid-February is the worst, I guess you just have to wear a lot of layers.

It is finally warm out, I do not want to be hopeful in case it snows again.

Most sessions began with Harold commenting on extreme heat, extreme cold, removing extra layers, or every now and then enjoying, if tentatively, a beautiful day. Had I been more attuned to the more-than-human environment in sessions, less unsure about how to work with my own evolving countertransference, I might have realized that Harold was talking about more than just the weather. Rain, heat, snow, cold, ice, wind, sun-all states of the more-than-human environment and their impingement on him were noted as were the ways he found to respond to them: how safe or not he felt, how crazy or not he found it, the uncertainty of allowing himself to be hopeful.

Harold experienced the weather sometimes as treacherous, sometimes seductive, but he never stopped exposing himself to it, finding ways to work with it. The omnipresence of the more-than-human environment was an essential part of his lived experience, which he seemed to convey unconsciously to me in the transitional moments at the start of each session, and which I, perhaps equally unconsciously, failed to recognize. We might understand Harold to be weathering, an idea developed by cultural theorists Astrida Neimanis and Rachel Loewen Walker (2014). Neimanis and Walker call attention to how we, particularly our bodies, like the rest of the more-than-human environment, weather the world. Without obliterating the important distinction between climate and weather, they emphasize that the former is not only abstract data, as many of us higher up in the climate-caste system still experience it, but is on-going, immediate, within and around us. Neimanis and Walker suggest that opening ourselves up to how we are permeable, to living this intensity, might allow us to address larger effects in climate. Persisting, getting on, getting through, or weathering, offer evocative ways of understanding how some come to hold trauma in an embodied state and can think about our catastrophically changing climate. 
In retrospect, I sense a connection between Harold's lived experience of repetitive early childhood trauma, the multiple ways he found to weather it, and his willingness to be permeated by the more-than-human environment. Harold's capacity for catastrophic thinking as well as his traumatized sensibility express themselves in these early moments of transition into a session as well as in his openness to being with his feelings about trauma, past, present and future. Regrettably, I am only able to find language for this now that our work has ended. I continue to wonder what Harold's trajectory might have looked like had my own mind been more available to help him translate his catastrophic thoughts into action.

Ricardo, a twenty-eight-year-old man of Puerto Rican descent, who endured a similar history of early violent trauma at the hands of one of his parents, voiced considerable and repeated distress over the years about the change of seasons in New York, and how difficult it was to know how to dress at these times of what have now become extreme and unpredictable transition. In contrast to Harold, who exposed himself to the weather at a very direct level, Ricardo felt incapacitated by it, defending himself against the possibility of weathering on all fronts. A little further along in my own training and analysis at this point, I was now better able to address what seemed silent in the room and help Ricardo feel, link and learn from his experiences of the more-than-human environment. I asked Ricardo if he felt there might be a connection between his upset about the extreme weather transitions and ways in which he might (or might not) sense our changing climate. He replied:

Yes, I do think that [global warming] is upsetting me. I mean, I don't like it being $40^{\circ}$ [about $+4^{\circ}$ Celsius] degrees in the middle of May and $90^{\circ}\left[+30^{\circ}\right.$ Celsius] at the end of October, and I can even see how the temperatures have changed from when I was a child. It is very scary. It even makes me not want to have children, like what sort of world am I bringing them into, what sort of life will they have.

This particular session began with his memories of the weather as a child in New York City and moved toward memories of early abuse at the hand of one his parents. His distraught comment, "I just wish these memories weren't there," speaks to both to the environment of his family growing up and the larger environment to which they belong. Ricardo began to feel the experiential links between the catastrophic state of the more-than-human environment and his own familial encounters with catastrophe. Weaving in and out of these themes, he ended this session unusually with a direct question to me, as if to underline that there was no neutral way for me to separate myself from these planetary changes, or no analytic position outside of climate change, no way to maintain an anenvironmental 
orientation. "Do you think other people are affected by climate change, too, and maybe don't know it?"

In contrast to Anna and Harold, who articulated an awareness of climate breakdown, Ricardo entered therapy in a state more strongly dissociated from his childhood traumas, making every effort, including substance abuse, to feel impermeable to what he had experienced. As we began to move toward and learn from his experiences of these traumas, and he found himself more able to think in these spaces, a permeability to changes in the climate became a part of his process as well. He began to think catastrophically about his own individual past as well as his shared present and future. Ricardo developed a capacity to know, hold and learn from, or weather, his own experiences in ways that resonated with others, a capacity that by then included almost five years of sobriety. What started as an understandable defense against thinking trauma as well as weathering weakened as he came to trust that together we could name his parental and planetary dread. While Ricardo's heightened sensibility for weather remained, my sense is that this meant he was working out for himself a more livable state of permeability to reality, both with regard to past personal trauma and current climate breakdown (Bion, 1957, p. 267). Although I did not realize it then, time spent with Harold both during our work together, and in my mind after, taught me in ways that I could bring to Ricardo. Learning from the experience of my own anenvironmental orientation allowed me more confidence in extricating myself from my "unconscious collusion with the social norm" (Layton, 2006, p. 114), which maintained an illusory if felt separation between the psychic and the morethan-human environment.

This capacity to think catastrophically, to disrupt an unconscious anenvironmental orientation and learn from the experience of trauma-to weather-may also offer insight into studies which find that, in very broad terms, those with less power in our society, for example because of gender or ethnicity, seem more open to recognizing the realities of climate change (Ballew, Marlson, Leiserowitz \& Cutler, 2018; Leiserowitz, Rosenthal \& Cutler, 2018). As Layton reminds us, "nonwhite minorities, for example, are far less likely to buy into the unlinking norm than are whites of all classes" (Layton, 2006, p. 109). Poignantly, even problematically, the concept of "weathering" itself was originally used by public health scholar, Arline Geronimus, to describe the poorer health outcomes of African-American women as a result of their experiences of cumulative and on-going trauma (Geronimus, 1996; Warren-Findlow, 2006). The powerful words of Ta'Nahisi Coates describe this impact of systemic trauma: 
When their [white people's] own vulnerability becomes real - when the police decide that tactics intended for the ghetto should enjoy wider usage, when their armed society shoots down their children, when nature sends hurricanes against their cities - they are shocked in a way that those of us who were born and bred to understand cause and effect can never be. (Coates, 2015, p. 107).

To extrapolate from Harold Searles's suggestion that some may ignore environmental degradation to keep their own idealized childhood intact, it may be that those with less-than-ideal childhoods have less invested in preserving any early fantasy or believing that they can unlink themselves from the more-than-human environment (Searles, 1972, p. 366; Searles, 1960).

Something about learning from traumatic experiences may make (some) fantasies less necessary for survival. Psychoanalysts Paul Hoggett and Rosemary Randall find similar dynamics in their study on how climate scientists and activists differ in their approaches:

Where the activists openly acknowledged the traumatic edge to many of their experiences, and had developed quite sophisticated ways of dealing with that, the scientists were more likely to discuss the traumatic experiences of others, moving attention away from themselves, and they seemed to have fewer resources to cope with their own dark or despairing feelings (Hoggett \& Randall, 2018, p. 239).

Hoggett and Randall find activists better able than the scientists to sustain their work because of their permeability to its traumatic nature as opposed to the defensive stance of the scientists. Perhaps unsurprisingly then, some of the concepts on which I lean heavily, such as thinking and learning from experience, come from Wilfred Bion. Indelibly marked by the brutal events of World War 1, Bion's own permeability and capacity to learn from his traumas may have contributed to his formulation of such generative concepts and his conception of mental life as "an endless shuttle between primitive terror and mature insight" (Souter, 2009, p. 801; Brown, 2010, p. 677).

\section{A TRAUMATIZED SENSIBILITY}

People who have learned to think catastrophically, to go-on-being and acting while keeping personal and planetary traumas in mind, can teach us something. In terms of the on-going and future traumas that our hotter planet promises, the articulation of a traumatized sensibility may offer one way to counter the unthinking states in whose grip too many of us are. Given the likelihood that no one will overcome or recover from climate 
trauma in any permanent way, this articulation may aid us in the necessary task of revisiting and re-contextualizing "all that we have learned about trauma in the past century" (Woodbury, 2019, p 3). Below, I offer a provisional outline of what might constitute a traumatized sensibility, that is, a productive capacity to think and act upon catastrophic thoughts on our changing planet. My outline is analogically based on clinical, cultural, and personal experiences with people who have struggled and found generative ways to go on living in their own overturned, catastrophic worlds. ${ }^{6}$ The sensibility seems to move in tandem with an awareness of permeability to a more-than-human environment as well as the social and environmental collapses now at hand.

A traumatized sensibility has learned from experience that annihilation is thinkable. It can bear the tragic, the feeling of irreparable brokenness, or in environmental terms, that we have entered a time of post-sustainability. There is a living memory, or awareness, or ability to imagine the inevitability of repeated collapse, social and otherwise, violence and war. And yet, an ability to think and translate thinking into action in a state of precarity is maintained. The world is not assumed to be safe.

Just as annihilation is thinkable, despair is bearable. A traumatized sensibility does not resist but can tolerate despair, and continue being, thinking and acting in the world. Many analytically-minded people thinking about climate breakdown, especially in the U.K. (for example, Weintrobe, 2012), understandably find the Kleinian ideas of a paranoid-schizoid and depressive position relevant. If, however, we follow Hanna Segal's assertion that a necessary precondition for the depressive position is "a predominance of good over bad experiences" (Segal, 1964, p. 37), is a depressive position, as well as its attendant reparations, tenable in the midst of climate collapse?

Catastrophic climate change suggests instead that we will be learning to live with and mourn losses on what is for many of us an unprecedented scale. While the linguistic history of "hope" relates to a leap (of faith), presupposing a place to land, the etymological roots of despair, namely "without hope," may better describe our hotter planet's new reality principle (Partridge, 1958, pp. 295 and 148). As any gathering of two or more analysts working in this area indicates, controversial discussions predominate around the necessity of hope. After exploring the discussion among climate scientists as to the effectiveness of hope as opposed to fear in more public discussions, Wallace-Wells arrives at a conclusion I share: "It is okay, finally, to freak out" (Wallace-Wells, 2019, p. 157; Craps \& Olsen, 2020, p. 114; Jordan, 2018; LaMothe, 2020, pp. 145-146; Melmed, 2020, pp. 346-347).

Our hotter planet also teaches us that powerlessness, dependence and despair need not mean a loss of agency or a foreclosure on social, political 
or psychic action. Vulnerability does not mean weakness. A traumatized sensibility can draw strength from vulnerability and dependence rather than erect defenses, or in Harold's words, "I got where I am because I led with my vulnerability." Instead of hardening and splitting, we can soften and open, allowing ourselves to weather, to experience how microclimates are embedded in a larger world, as Harold did when biking to sessions. We can allow ourselves to recognize the reality of our permeability to that which is both larger and smaller than ourselves (For related perspectives on vulnerability see Alaimo, 2016; Butler, 2016, 2020).

A traumatized sensibility acknowledges living in a material body, a body that is and is not one's own, a body subject to wounding, to degradation, to weathering. Our bodies are not, and have never been, invulnerable, impermeable or immaterial. They are porous and fragile, flammable, floodable, subject to infection, as the on-going pandemic reminds us. Much as our besieged psyches might wish it were otherwise, our bodies refuse any paranoid-schizoid, defensive splits, instead exhibiting what Gaia-theory biologist Lynn Margulis called the "blur of distinctions" between living and non-living (Scofield \& Margulis, 2012, p. 229). Inanimate and animate, micro- and macroscopic worlds coexist, a continual dynamic of cell birth, growth and death. Externalization and internalization are more difficult, broken skin is livable. Inside is outside, outside is inside. We are embedded, we are enmeshed across multiple scales of spaces and times. In some psychoanalytic thinking, enmeshment is often seen as pathological. Yet, I have found especially in my work with people from non-dominant cultures, who often carry more cultural and systemic trauma, that they can live this enmeshment productively.

A traumatized sensibility knows that the temporality of trauma is different, non-linear, or as Katie Gentile drawing on Neimanis and Walker describes it: dense (Gentile, 2020; Woodbury, 2019, p. 6). People thinking about the psyche, beginning at least as early as Freud and Janet, generally conceive of trauma in the past, to be worked through, reconstructed and remembered, often in the relatively safe space of an office. No matter how horrific the traumas they described, trauma theories generally developed during an era in which the background of natural phenomena was assumed stable, a now decidedly unstable assumption (Wark, 2017, p. 4). Many practicing psychoanalysts today, and I suspect all of us sooner rather than later, will be unable to follow trauma theorist Bessel van der Kolk in "help[ing] our patients live fully and securely in the present" (Van Der Kolk, 2014 , p. 72) any more than we will be able to help ourselves to do so. The reality of a "relatively [...] predictable present that lives side by side with a ruinous ever present past" (p. 195; see also pp. 180, 20, 66), which underlies many a therapeutic holding environment, is irreparably disrupted. 
We have usually met trauma retrospectively, reflecting on a chaotic past in a potentially more stable present. In contrast, climate change promises that stability is a thing of the past, with increasing chaos and mass extinction in the present and future.

The traumas we will be experiencing will not be mastered by repetition, or mastered at all, but will require new ways of approaching and understanding. I think here of a subject in and survivor of the thick of trauma, in contrast to Catherine Malabou $(2007,2015)$ and Slavoj Žižek (2009, 2018), who write of a post-traumatic subject. For them, posttraumatic subjects do not psychically survive their trauma, developing a form of subjectivity that appears "autistic, indifferent, deprived of affective engagement" (Žižek, 2018, p. 296; see also p. 293). They, too, however, acknowledge the idea of post-trauma as a potential misnomer, for example, for people in war-torn countries like Sudan or Congo: "It is almost an oxymoron to refer to them as 'post-traumatic' subjects, since what makes their situation is the very persistence of trauma" (Žižek, 2018, p. 293).

A traumatized sensibility knows that human exceptionalism is not real. (See also Gentile, 2020). Especially for those who were traumatized early at the hands of adults, frequently caregivers, the fantasy that those in power know what they are doing, that we can leave things up to the authorities, or that humans will figure things out, is hard to sustain. Home writ small and large, whether parental or planetary, may not be safe, it may be a place of violent disregard; and yet some find their way in a hostile holding environment that refuses any projections. Decentering the human and destabilizing human exceptionalism move in tandem. ${ }^{7}$

A traumatized sensibility goes on learning from experience, rather than solely letting experience happen. A transformation is enabled by the analytic process. Curiosity about, rather than hatred of, the permeable nature of our inner and external realities, predominates, as does a desire to notice the on-going links and contextual dependencies between them. Analysts need to receive, contain, and modify the feelings and projections of the people we work with clinically. Otherwise, as Bion suggests, we find ourselves confronting a

severe disorder of the impulse to be curious on which all learning depends [...] feelings of hatred are thereupon directed against all emotions including hate itself and against external reality which stimulates them. It is a short step from hatred of the emotions to hatred of life itself. (Bion, 1959, pp. 312 and 314).

This containment and modification, allowing for the other's safe reintrojection of their fears, enables learning from experience to happen. To facilitate such learning from experience, psychoanalysis may need to acknowledge its educative impulses, replacing the pleasures of stable eco- 
systems with the realities of an increasingly unstable, hotter planet, or of a pleasure-ego with a new reality-ego. (Freud, 1911, p. 224). Increasingly, we analysts are contextualizing for ourselves and the people we work with clinically the ways in which growing up LGBTQ in a homophobic, heterosexist society, poor or rich in a late-capitalist, neo-liberal society, white or Black in a racist, white supremacist society, shapes our unconscious and conscious lives. Likewise, we need to contextualize what it means to be living and participating in a more-than-human environment in the waning days of petromodernity, whether we choose to defend against this fact with an anenvironmental orientation or remain permeable to it.

A traumatized sensibility allows for the unsayable to be said, although in my experience, not alone. It does not inevitably mean denial, disavowal, or foreclosure. But, until analysts are able to speak about this on-going trauma, the majority of people with whom we work clinically continue to be left alone with their unarticulated fears about what is happening on the planet. Together, we need to name the dread and try to make it potentially tolerable. We can reject the position of "willfully misunderstanding" (Bion, 1962 , p. 309) by not speaking about the permeability of our internal and external realities, instead providing space and guidance for verbal thought, for symbolization and for linking. We can refuse to let each other and ourselves experience a "starvation of truth" (Bion, 1962, p. 310). As Bion reminds us, with articulated speech "problems can be solved because at least they can be stated whereas without it certain questions, no matter how important, cannot even be posed" (Bion, 1957, p. 274; Stolorow, 2020).

And, finally, vitality and vibrancy, life itself, are not incompatible with a traumatized sensibility. The reality principles of joy, delight, kindness, beauty, wonder, compassion, creativity, humor, growth and grace abide.

An important and significant difference about a traumatized sensibility as it relates to climate breakdown, and the sensibilities of those who have suffered extreme personal, often early, trauma, is that the latter generally are not complicit in their traumatization. With our hotter planet, far too many of us, especially those of us living privileged first-world lives in first-world countries, are implicated, albeit here, too, to vastly different degrees. Many of us are simultaneously witnesses and perpetrators, beneficiaries and victims, complicit in the ways we sustain political, social, and cultural structures that are carbon intense and environmentally degrading. Children erroneously blame themselves, whereas many of us, equally erroneously, do not. As clinicians, we often work with adults who need help thinking and linking, recognizing and experiencing their traumatic histories, allowing themselves to become more permeable to them. As clinicians working in the midst of a "sixth extinction," accelerating and caused by human desecration, our role may be similar. That is, we remain present to help 
people think and link, recognize, and own their experiences but what needs to be experienced, thought, and acted upon are, among other things, one's contributions to the destruction of our climate and the larger structural context. Acknowledging and acting upon our individual and collective complicity in environmental destruction is one form among many that our responsibility can take.

\section{THINKING AND THANKING}

To be thinking catastrophic thoughts-to be working within and not solely through persistent trauma-may be some of the hardest tasks, psychic and otherwise, facing us as we confront what we are doing on and to our planet. Rather than pathologize catastrophic thinking, we can consider its cultivation, as it may allow us to metabolize and act upon the realities of the climate and ecological systems breaking down. And rather than see ourselves as treating the traumatized, we can begin to recognize our shared vulnerability, letting the traumatized teach us. Together we can learn from our collective experiences of living on our hotter planet so that we might begin to think more catastrophically and act with heart if not hope. In sketching the contours of catastrophic thinking as well as a traumatized sensibility, I hope to have added my voice to a growing chorus of psychoanalytically-minded people showing us what psychoanalysis has to offer in the struggle to help us to think about and hold conflicts and ambivalence (Gentile, 2020), and to revisit trauma (Woodbury, 2019).

In his 1910 essay about primal words, Freud concluded: "we would ${ }^{8}$ be better at understanding and translating the language of dreams if we knew more about the development of language" (Freud, 1910, p. 161). In this spirit, we might recall that "think" and "thank" derive from the same root (Partridge, 1958, pp. 713-714). Perhaps as we come to cultivate more, albeit catastrophic thinking in our lives and practice, we can become more conscious of a renewed thankfulness to be alive at all.

\section{NOTES}

1. Susan Kassouf, PhD, Licensed Psychoanalyst and a candidate at the National Psychological Association for Psychoanalysis (NPAP). She has written and presented about climate change and psychoanalysis, co-founded with colleagues the Steps on Sustainability Committee at NPAP, and participates in several study groups grappling with environmental degradation from an analytic perspective. She has also translated works by and about Erich Fromm. After receiving her PhD from Cornell University, she taught at Vassar College in 
German Studies, where she wrote about literature, film, gender as well as pedagogy. She served as Senior Adviser at The Endeavor Foundation, where she worked as the Program Officer for many years.

2. For a more detailed discussion of the anenvironmental orientation, see "A New Thing Under the Sun" (Kassouf, 2021). Relying on the Greek prefix "an" meaning "without" or "lacking", I understand anenvironmental to describe something without or lacking the environment, in much the same way that we understand amoral to mean "without morals" or anaerobic to mean "without oxygen." In other words, an anenvironmental orientation to the world and self means an orientation without or lacking the environment. The idea of an anenvironmental orientation is indebted to Erich Fromm's work about non-productive social character orientations, such as the authoritarian, narcissistic and marketing orientations. (See Fromm, 1941).

3. This is a time when "surprising new creative thought becomes available when one is "cracked open" without the interference of a belittling authoritarian presence," writes Vida about her own experience (Vida, 2003, p. 42). [Eds.]

4. In his paper, Francisco Balbuena (2018, pp. 291-296) draws attention to Harold Searles' first book, The Nonhuman Environment in Normal Development and in Schizophrenia (Searles, 1960), and its main theme, the exploration of the nonhuman environment in a person's psychological experience. Searles considers "non-human environment" the totality of a person's environment, except for the other human beings in it (Searles, 1960, p. 3). In his work on dignity, Salman Akhtar (2015) "finds it lamentable that Searles' work remains to be unread, since the nonhuman environment is part of 'metaphysical dignity', which contributes to an individual's psychic development in significant ways" (Balbuena, p. 291). Searles himself was greatly disappointed that the American psychoanalytic establishment never had a good word to say about this work (p. 292), however, Winnicott (with Silvia Payne) [Payne \& Winnicott, 1963], found the idea of closely studying the role of the nonhuman environment in human development sound, and long overdue (Balbuena, p. 294). [Eds.].

5. Contemplating the role of the nonhuman environment has been neglected in psychoanalytic training, starting with the early days of psychoanalysis. "Searles (1960) says that Freud was so fully occupied with making his innumerable great discoveries concerning the psychological processes that transpire within humans that he rarely found time for a detailed search into this other dimension of human psychological existence. But more important for us is Searles's explicit acknowledgement of the significance of the "nonhuman environment" in the psychological life of humans, especially in the early stages of development. Searles commented: "(...) It is my conviction that there is within the human individual a sense, whether at a conscious or unconscious level, of relatedness to his nonhuman environment, that this relatedness is one of the transcendentally important facts of human living, that-as with other important circumstances in human existence-it is a source of ambivalent feelings to himself, he does so at the peril to his psychological wellbeing (Searles, 1960, p. 6)." (Balbuena, pp. 293-294) [Eds.]

6. My effort to articulate this sensibility is inspired by but also differs from several others making important contributions in the specific area of trauma and climate. Instead of moving toward trauma, Brulle and Norgaard (2019) explore resistance to the cultural trauma of climate change as contributing to our collective inertia in addressing it. While beautifully articulating the necessity of a new understanding of (Climate) Trauma, Zhiva Woodbury suggests considering that the "most traumatized segments of our society [...] are the most dismissive of climate science," whereas I suggest that early interpersonal traumatic experiences can leave people less not more defended against the realities of climate breakdown (Woodbury, 2019, p. 6). E. Ann Kaplan makes a compelling case for 
the existence of climate-related pre-traumatic stress with less focus on the here and now (2020).

7. Wallace-Wells (2019) asks some tantalizing questions about human exceptionalism, such as "Why should we be suspicious of our exceptionality, or choose to understand it only by assuming an imminent demise? Why not choose to feel empowered by it?" (p. 225). I would ask if empowerment necessarily requires a sense of exceptionality.

8. Strachey translates this as "should," but I find "would" equally appropriate and have amended accordingly.

\section{REFERENCES}

Akhtar, S. (2015). Some psychoanalytic reflections on the concept of dignity. American Journal of Psychoanalysis, 75, 458-461.

Alaimo, S. (2016). Exposed. Environmental politics and pleasures in posthuman times. Minneapolis, MN: University of Minnesota Press.

Albrecht, G. (2020). Negating solastalgia: An emotional revolution from the Anthropocene to the Symbiocene. American Imago, 77(1), 9-30.

Allured, E. (2018). Holding the un-grievable: A psychoanalytic approach to the environmental crisis. [Book Review]. Climate Crisis, Psychoanalysis, and Radical Ethics by Donna M. Orange. New York, NY: Routledge, 2017. Contemporary Psychoanalysis, 54(1), 239-246.

Balbuena, F. (2018). Harold Searles: Lifelong work of a master clinician. American Journal of Psychoanalysis, 78, 287-306.

Ballew, M., Marlson, J., Leiserowitz, A. \& Cutler, M. (2018). Gender differences in public understanding of climate change. http://climatecommunication.yale.edu/ publications/gender-differences-in-public-understanding-of-climate-change/.

Bendell, J. (2018). Deep adaptation: A map for navigating climate tragedy. https:// www.lifeworth.com/deepadaptation.pdf.

Bion, W. R. (1957). Differentiation of the psychotic from the non-psychotic personalities. International Journal of Psycho-Analysis, 38, 266-275.

Bion, W. R. (1959). Attacks on linking. International Journal of Psycho-Analysis, 40, 308-315.

Bion, W. R. (1962). The psycho-analytic study of thinking. International Journal of Psycho-Analysis, 43, 306-310.

Bonoir, A. (2016, November). 5 ways to stop catastrophizing. Psychology Today. https:/www.psychologytoday.com/us/blog/friendship-20/201611/5-ways-stopcatastrophizing.

Brown, L. J. (2010). Klein, Bion, and intersubjectivity: Becoming, transforming, and dreaming. Psychoanalytic Dialogues, 20(6), 669-682.

Brulle, R. J., \& Norgaard, K. M. (2019). Avoiding cultural trauma: Climate change and social inertia. Environmental Politics, 28(5), 886-908.

Butler, J. (2016). Rethinking vulnerability and resistance. In J. Butler, Z. Gambetti, \& L. Sabsay (Eds.), Vulnerability in resistance (pp. 12-27). Durham, NC: Duke University Press.

Butler, J. (2020). On rethinking vulnerability, violence, resistance. March 6. https:// www.versobooks.com/blogs/4583-judith-butler-on-rethinking-vulnerabilityviolence-resistance.

Coates, T. (2015). Between the world and me. New York, NY: Random House. 
Craps, S., \& Olsen, I. (2020). Grief as a doorway to love: An interview with Chris Jordan. American Imago, 77(1), 109-135.

Ellis, A. (1962). Reason and emotion in psychotherapy. Secaucus, NJ: Citadel P.

Freud, S. (1910). The antithetical meaning of primal words. Standard Edition, Vol. 11, (pp.153-162). London: Hogarth.

Freud, S. (1911). Formulations on the two principles of mental functioning. Standard Edition (Vol. 12, pp. 213-226). Hogarth.

Fromm, E. (1941). Escape from freedom. New York, NY: Open Road Media. 2013.

Gentile, K. (2020). Transcorporeal becoming: The temporalities of Searles and the nonhuman. Subjectivity, 13(3), 179-199.

Gore, A. (2006). An invonvenient truth. Transcript. https://meigakuglobalchallenges. files.wordpress.com/2012/02/an-inconvenient-truth-transcript.pdf (pp. 1-48).

Geronimus, A. T. (1996). Black/white differences in the relationship of maternal age to birthweight: A population-based test of the weathering hypothesis. Social Science Medicine, 42(4), 589-597.

Greenberg, J. R., \& Mitchell, S. A. (1983). Object relations in psychoanalytic theory. Cambridge, MA: Harvard University Press.

Guggenheim, D. (Director). (2006). An inconvenient truth: A global warning [DVD]. Hollywood, CA: Paramount.

Herman, J. L. (1992). Trauma and recovery. The aftermath of violence-From domestic abuse to political terror. New York, NY: Basic Books. 2015.

Hoggett, P., \& Randall, R. (2018). Engaging with climate change. Comparing the cultures of science and activism. Environmental Values, 27(3), 223-243.

Jarvis, B. (2020, July 21). The teenagers at the end of the world. New York Times Magazine, The Climate Issue. https://www.nytimes.com/interactive/2020/07/21/ magazine/teenage-activist-climate-change.html

Jordan, C. (2018, October 17). We live in a s**t show but denying our despair could make everything worse. Huffington Post. https://www.huffpost.com/entry/ despair-environment-politics_n_5bc5d910e4b0a8f17ee5d240.

Kaplan, E. A. (2020). Is climate-related pre-traumatic stress syndrome a real condition? American Imago, 77(1), 81-104.

Kassouf, S. (2021). A new thing under the sun. ROOM: A sketchbook for analytic action. http://www.analytic-room.com/essays/a-new-thing-under-the-sun-by-susan-kassouf/

LaMothe, R. (2020). On being at home in the world: A psychoanalytic-political perspective on dwelling in the Anthropocene era. Psychoanalytic Review, 107(2), 123-151.

Layton, L. (2006). Attacks on linking. The unconscious pull to dissociate individuals from their social context. In L. Layton, N. C. Hollander, \& S. Gutwill (Eds.), Psychoanalysis, class and politics: Encounters in the clinical setting (pp. 107-117). New York, NY: Routledge.

Leiserowitz, A., Rosenthal, S., \& Cutler, M. (2018, June 14). Latinos and global warming's six Americas. [Climate Note]. Yale Program on Climate Change Communication. https://climatecommunication.yale.edu/publications/latinosand-global-warmings-six-americas/

Lifton, R. J. (2017). The climate swerve. Reflections on mind, hope and survival. New York, NY: New Press.

Malabou, C. (2007). Les Nouveaux Blessés: De Freud a la neurologie: Penser les traumatismes contemporains. Paris: Bayard. The New Wounded: From neurosis to brain damage. New York: Fordham University Press. 2012. 
Malabou, C. (2015). Post trauma: Towards a new definition? In M. Pasquelini (Ed.), Alleys of your mind: Augmented intellligence and its traumas (pp. 187-198). Leuphana University of Lüneburg: Meson Press. https://doi.org/10.14619/014

Melmed, M. L. (2020). Bound by infinities: Technology, immediacy and our environmental crisis. American Journal of Psychoanalysis, 80, 342-353.

Merriam Webster Dictionary online. https://www.merriam-webster.com/dictionary. Mitchell, S., \& Greenberg, J. (1983). Object relations in psychoanalytic theory. Cambridge, MA: Harvard University Press.

Morton, T. (2013). Hyperobjects: Philosophy and ecology after the end of the world. Minneapolis: University of Minnesota Press.

Morton, T. (2016). Dark ecology. For a logic of future coexistence. New York, NY: Columbia University Press.

Neimanis, A., \& Walker, L. (2014). Weathering: Climate change and the thick time of transcorporeality. Hypatia, 29(3), 558-575.

Ogden, T. (2010). On three forms of thinking: Magical thinking, dream thinking, and transformative thinking. Psychoanalytic Quarterly, 79(2), 317-347.

Orange, D. M. (2016). Climate crisis, psychoanalysis, and radical ethics. New York, NY: Routledge.

Partridge, E. (1958). Origins. A short etymological dictionary of modern English. New York, NY: Macmillan.

Payne, S. M., \& Winnicott, D. L. (1963). The nonhuman environment in normal development and in schizophrenia (Book Review). International Journal of Psychoanalysis, 44, 236-238.

Scofield, B., \& Margulis, L. (2012). Psychological discontent: Self and science on our symbiotic planet. In P. H. Kahn \& P. H. Hasbach (Eds.), Ecopsychology. Science, totems and the technological species (pp. 219-239). Cambridge, MA: MIT Press.

Searles, H. (1960). The Nonhuman Environment in Normal Development and in Schizophrenia. New York, NY: International Universities Press.

Searles, H. (1972). Unconscious processes in relation to the environmental crisis. Psychoanalytic Review, 59(3), 361-374.

Segal, H. (1964). Introduction to the work of Melanie Klein (p. 2018). Routledge.

Souter, K. M. (2009). The war memoirs: Some origins of the thought of W. R. Bion. International Journal of Psycho-Analysis, 90(4), 795-808.

Stolorow, R. (2020). Planet Earth: Crumbling metaphysical illusion. American Imago, 77(1), 105-107.

Van der Kolk, B. (2014). The body keeps the score: Brain, mind, and body in the healing of trauma. New York, NY: Penguin.

Vida, J. (2003). Not "Filed away as finally dealt with." American Journal of Psychoanalysis, 63, 39-47.

Vollman, W. (2018). Carbon ideologies. No immediate danger. Volume 1. New York, NY: Penguin Random House.

Wallace-Wells, D. (2019). The uninhabitable earth. Life after warming. New York, NY: Duggan Books.

Wark, M. (2017). General intellects. Twenty-one thinkers for the twenty-first century. New York, NY: Verso.

Warren-Findlow, J. (2006). Weathering: Stress and heart disease in African American women living in Chicago. Qualitative Health Research, 16(2), 221-237.

Weintrobe, S. (Ed.). (2012). Engaging with climate change. Psychoanalytic and interdisciplinary perspectives. New York, NY: Routledge. 
Woodbury, Z. (2019). Climate trauma: Toward a new taxonomy of trauma. Ecopsychology, 11(1), 1-8.

Žižek, S. (2009). Descartes and the post-traumatic subject: On Catherine Malabou's les nouveaux blessés and other autistic monsters. Qui Parle: Critical Humanities and Social Sciences, 17 (2), 123-47. [Review of Malabou's 2007 article.] Žižek, S. (2018). Living in the end times. New York, NY: Verso.

Publisher's Note Springer Nature remains neutral with regard to jurisdictional claims in published maps and institutional affiliations. 